\title{
TERÜLETISÉG AZ ADÓRENDSZERBEN: A TERÜLETI GONDOLKODÁS MEGJELENÉSE EGY PÉNZÜGYMINISZTÉRIUMI DOKUMENTUMBAN
}

\author{
(Space in the Tax System: The Appearance of Regional Think- \\ ing in a Document of the Ministry of Finance)
}

\section{JAKOBI ÁKOS}

Évek óta, mondhatni immár tradíciószerủen, a köztársaság pénzügyminisztere irányelveket fogalmaz meg az Adó- és Pénzügyi Ellenörzési Hivatal (APEH) számára a lakosság jövedelemadó-bevallásának kiegészítésére történő felhíváshoz. Az adózás rendjéről szóló 1990. évi XCI. törvény (Art.) 60. §-ának (7) bekezdésében kapott felhatalmazás alapján a pénzügyminiszter az 1999. évre vonatkozóan is kiadta a végrehajtás elősegítése érdekében a felszólitás ezen évre vonatkozó értékeire és szempontjaira az irányelveit, melyek a 7002/1999. (PK. 13.)-as szám alatt jelentek meg.

A regionális tudomány illetve a területi statisztikai elemzések szemszögéböl nézve tulajdonképpen teljesen érdektelen lenne a pénzügyminiszternek a jövedelemadó-bevallással kapcsolatban közzétett dokumentuma. Az ügy érdekességét viszont az a kérdés jelenti, hogy miként jelenik meg a területiség egy kormányzati intézmény, a Pénzügyminisztérium $(P M)$ szemléletében, továbbhaladva pedig vajon nyerhetünk-e kiegészitö információkat a jövedelemszint területi különbségeiröl e dokumentumokat elemezve.

A fent említett 7002/1999-es dokumentum az önálló tevékenységet folytató magánszemélyek jövedelemadó-bevallásának kiegészítésére történő felhíváshoz fogalmaz meg irányelveket, mely elvek az állami adóhatóság számára készültek az egyszerübb és hatékonyabb mủködés és feladat-végrehajtás érdekében. A pénzügyminiszter által megfogalmazott irányelv lényege, hogy az állami adóhatóság felhívja azokat az adózókat - az adóbevallást követően - a bevallásban közölt adatok kiegészítésére, akiknek a bevallott jövedelme nem éri el a mindenkori minimálbérre, a tevékenység gyakorlásának körülményeire, a szakmai és területi sajátosságokra figyelemmel kialakított összeghatárokat.

Abban az esetben, ha a fenti szempontok alapján az adózó felszólítást kap, a magánszemélynek az adóévben szerzett összes jövedelem (bevétel) felhasználásáról (kiadásáról, ráforditásáról, befektetéséről), továbbá annak forrásairól nyilatkozatot kell tennie. Ezt követően az adóhatóság megvizsgálja, hogy a nyilatkozatban megjelölt felhasználásra (kiadásra...) a magánszemély bevallott jövedelme és egyéb forrása nyújthatott-e elegendö fedezetet. Amennyiben nem, úgy az adóhatóság a magánszemélyt adóellenőrzésre választja ki, vagy az adóhatóság a magánszemély adóalapját olyan összegben állapítja meg, amely a tevékenység jellegére, az eset 
összes körülményeire tekintettel valószínüsíthetö. Innentöl kezdve pedig az Art. VI. és VII. szakaszának paragrafusai szerinti rendelkezések lépnek érvénybe.

A Pénzügyminisztérium az irányelvhez csatolva a minimális éves jövedelmek javasolt összeghatárait is mellékelte, mégpedig egyes szakmákra, tevékenységekre vonatkozóan, illetve megyei és településnagyság szerinti bontásban. Lényegében ez a táblázatszerủ adatsor vagy inkább számhalmaz szolgál segítségül az APEH dolgozóinak a bevallás-kiegészítésre történö felhívások elkészítéséhez, ugyanakkor a területi folyamatokat kutató szakemberek is érdekes vizsgálati alapadatokat vélhetnek felfedezni.

Három fö kérdéscsoportot érdemes alaposabban megvizsgálni:

1) Milyen módon jelenik meg a területiség, a térségi szemlélet a PM-ben? Milyen területi fogalmakat használ a PM (a vizsgált dokumentumban)?

2) Milyen területi-, térszerkezeti kép rajzolódik ki a dokumentumból?

3) Miként használható a dokumentum a jövedelmek területi vizsgálataihoz?

\section{1) Hogyan és milyen fogalomkörben jelenik meg a területiség a PM-ben?}

Kétségtelen, hogy a Pénzügyminisztérium nem a területi egyenlőtlenségek vizsgálatáért (és befolyásolásáért) felelös kormányzati intézmény. A területiség csak az ilyen intézményeknél ,,már megszokott módon”, például az egyes osztályok, PM alá rendełt társintézmények, hivatalok területi kirendeltségei, megyei vagy egyéb igazgatóságai formájában jelenik meg. Ez azonban távolról sem jelent egyet a térségérzékeny szemlélettel. Legtöbbször csak adminisztratív okokból, az ügyintézés hatékonyabb lebonyolítása érdekében alakítják ki az ehhez hasonló intézmények belsö struktúrájukat.

A területi különbözőségeken alapuló gondolkodás - akár egy PM jellegủ intézményben is - esetenként más formában is megjelenhet. Egy ilyen „másfajta” szemléletre lehet figyelmes az olvasó, amikor a bevezetésben említett dokumentumot elolvassa.

A dokumentum - mint azt elnevezése is mutatja - egy pénzügyminisztériumi irányelv, amely tehát csak egy - bizonyos számításokon alapuló - kiegészítés illetve segédanyag arra nézve, hogy az adóhatóság egyes körülmények között miként végezze munkáját. Teljes bizonyossággal állítható - és ezt elöre le is kell szögezni -, hogy maga az irányelv és a hozzá tartozó adatsor a területi jellemzőivel együtt kizárólag egy (halvány) útmutatás a társadalom egy bizonyos szük rétege jövedelmi helyzetének területi alakulásáról, söt kimondottan speciális jellegü adatsor, amely nem tekinthetö semmiféle valós vagy elvárt jövedelemszintnek a különféle térségi elemek vonatkozásában. Ez azért is fontos, mivel ennek következtében az egész vizsgálat során a területi jövedelemviszonyok felfogásának csak egy ilyen - tehát kevésbé konkrét - formájával foglalkozhatunk.

A területi elvek a PM-ben a szabályozási folyamat részeként jelennek meg. A kiadott irányelv többek között az adózás megfelelö végrehajtásához kötödő területi szabályozás megjelenési formája is. A térségi szemlélet vagy a területi elemeknek 
az irányításba, pontosabban a szabályozásba történö beemelése a PM-nek azt a (nem túl merész) feltevését igyekszik kézzel fogható (törvényszerủ) formában alátámasztani, mely szerint létezó jövedelmi különbségek vannak annak függvényében, hogy az adott adózó az országnak mely térségében él, hol végzi tevékenységét. Ez a látszólag determinisztikus kijelentés a minisztérium és az APEH jövedelemadó-bevallási statisztikáinak több évre visszamenő vizsgálati eredményeire alapul. Nem egy szakértői tanulmány jelenti ki, hogy - például az életfeltételekböl, helyi árszínvonalbeli különbségekböl stb. adódóan - a különbözö térségekben eltérő jövedelem érhetô el (azonos egyéb feltételek mellett is).

A területiség megjelenésének helyes értékeléséhez mindenekelött szükség van a fent említett irányelv alaposabb megismerésére.

Már a személyi jövedelemadó-rendszer bevezetése után világossá vált, hogy az adóbevallásra kötelezett adózók egyes körei nem teljesen valóságos személyi jövedelmi adatokat vallanak be. Az adóhatóság ilyen esetekben alaposabb vizsgálat alá vonja a kérdéses adóbevallásokat, és különféle valószinunsítési, becslési és bizonyítási eljárásokat indít el ${ }^{1}$.

Az adóhatóság többféle becslési módszert alkalmaz. Szigorúan módszertani oldalról nézve három elkülönülő típust lehet megemlíteni (Földes 1998; Szatmári 1995). Az első két módszer a tényvizsgálatok körébe tartozik. Az ún. kevesebbröl többre becslés módszerénél a bevétel vagy a kiadások egy részének ismeretében bizonylatok, adatok, nyilatkozatok beszerzésével, szemlével, próbagyártással, leltározással és más megfelelő módszerrel valószínüsíthetỏ az adóalap. Ilyen esetekben a becslés lefolytatását legtöbbször helyszíni adatszerző vizsgálatok elözik meg.

Ugyancsak tényadatok elemzésén nyugszik az adóigazgatási szaknyelvben ,gumiszabály"-ként ismert módszer, amely a jövedelem-felhasználás, a vagyongyarapodás és az életkörülmények vizsgálatán alapul. Ezt akkor alkalmazzák, ha az adózó magánszemély kiadásai bizonyítható módon meghaladják megszerzett jövedelmeinek egyuuittes összegét. Ekkor az adóhatóságnak meg kell becsülnie, hogy a magánszemélynek a vagyongyarapodásra és életvitele fedezetéül milyen nagyságrendü jövedelemre volt szüksége.

A két tényvizsgálati módszer mellett a harmadik becslési forma az összehasonlitó becslés. Abban az esetben, ha az elöbbi módszerekre a feltételek (iratok stb.) hiányában nincs lehetőség, az adóalapot az APEH az azonos időszakban hasonló tevékenységet, hasonló körülmények között folytató adózók adatainak felhasználásával állapítja meg. Ilyenkor a becslés alapján számított adóalaptól való eltérést az adózónak kell bizonyítania.

A 7002/1999-es dokumentum és az ezt megelöző években közzétett hasonló irányelvek egyáltalán nem nevezhetők becslési módszereknek vagy azokat szabályozó eszközöknek. Jelen esetben a becslési eljárást kiegészítö, azt segitő anyagról van szó, amely bizonyos feltételek között megelózi az adóhatóság jövedelembecslési akcioit.

A kormányzat sokéves bizonytalankodó magatartása és az adómorál hanyatlásának $^{2}$ lezárására 1996. január 1 -jétöl ${ }^{3}$ végre életbe lépett a Pénzügyminisztérium által 
kidolgozott és széles körben nyilvánossá tett irányelvek rendszere. A PM-ben megfogalmazott irányelv lényege, hogy megmondja az APEH-nek, mely esetekben szólítsa fel az adózót bevallásának kiegészítésére. Az irányelv - mint azt a bevezetöben már említettük - szakmákra és területegységekre bontva olyan éves jövedelmi összeghatárokat közöl, melynél kisebb bevallott értékeknél célszerü (illetve az adóhatóság számára kötelező) alaposabb vizsgálatot is végezni. A dokumentum létrehozásának célja egyrészt az adóhatóság munkájának könnyítése volt, így ugyanis az APEH megfelelő kritériumrendszerhez vagy szabályrendszerhez juthatott, amelynek segítségével végső soron egységesen és nagyobb mennyiségben foglalkozhatott az adóbevallások ellenörzésével. A közzétett irányelv másik és nem titkoltan fontosabbnak ítélt célja pedig a terelö hatás, azaz az adófizetőknek a valóságoshoz közelebbi jövedelem-bevallások elkészítésére való ösztönzése.

Az irányelv nem az adózó lakosság egészét érinti, kizárólag az önálló tevékenységet folytató magánszemélyek jövedelemadó-bevallásaival foglalkozik. E körbe tartozik különösen az egyéni vállalkozó, a mezőgazdasági kistermelö, a szellemi alkotói tevékenységet végző stb. Összlétszámukat tekintve egy 200 ezer fö körüli csoporttal van dolgunk, melynek túlnyomó többségét az egyéni vállalkozói kör adja. „... Az egyes adózói csoportok - elsősorban az egyéni vállalkozók - évről évre nominálisan is csökkenö jövedelmekröl adnak számot, bevételeiknek csak egy részét szerepeltetik a bevallásban, személyes felhasználásaik jelentős részét pedig a vállalkozás költségei között számolják el..." - volt olvasható a PM Adóigazgatási föosztályának jelentésében (Hadi 1995). Az irányelvek megalkotásával és a terelö hatás érvényre jutásával az adóhatóság e vállalkozói réteg adómoráljának javulását várta, amely - a számok tükrében nézve - úgy tünik már kézzel fogható sikerrel járt. Míg 1995-ben az egyéni vállalkozók 3,5 milliárd forint jövedelmet vallottak be, addig 1998-ban már egy nagyságrenddel többet (!), 31 milliárd forintot (forrás: PM Adóigazgatási főosztály), ami kétségtelenül nem írható kizárólag az infláció vagy a gazdasági élénkülés számlájára.

Az irányelv alá azonban az önálló tevékenységet folytató magánszemélyeknek sem a teljes köre tartozik. A dokumentum alapján nem kell figyelembe venni, például a kezdő vállalkozót, az átalányadózást választókat, a nyugtaadási kötelezettség alól felmentetteket, azokat a vállalkozókat, akiknek az egyéb forrásból származó bevallott jövedelmének összege meghaladja az az évi minimálbér összegét stb.

$\mathrm{Az}$ irányelv főként azt a réteget igyekszik megszürni, ahol a készpénzforgalom még hosszú ideig általános marad (pl. a lakossági szolgáltatásokban, a közvetlenül a lakosságnak értékesítő tevékenységekben), ezért a jövedelem, s egyáltalán a bevétel is nehezen mérhetö.

A területiségröl leginkább a dokumentum kialakításának és módszertanának bemutatásával együtt érdemes szólni. Az irányelv lényegi eleme a mellékletben közölt táblázatszerủ adatsor, amelyben tehát szakmák, megyék és településnagyságkategóriák szerint tüntették fel az adóbevallás kiegészitésére történö felszólitás kiválasztásához irányadó legkisebb jövedelmi határértékeket. Az 1. táblázat a dokumentumban található összeghatárokból ad ízelítöt. 
Jakobi Ákos : Területiség az adórendszerben: Tér és Társadalom 14. évf. 2000/2-3. 33-42. p.

TÉT XIV. évf. 2000 -2-3

Területiség az adórendszerben...

\section{TÁBLÁZAT}

A rakománykezelö szakmában dolgozó egyéni vállalkozók bevallás-kiegészitésre mértékadó jövedelmi összeghatárai 1999-ben (ezer Ft)

(Limited Amounts Concerning the Supplement of Income Return of Entrepreneurs Working in the Field of Stowing in 1999, in Thousand HUF)

\begin{tabular}{|c|c|c|c|c|c|}
\hline \multirow{2}{*}{$\begin{array}{c}\text { Szakmakód és } \\
\text { megnevezés }\end{array}$} & \multirow{2}{*}{ Megye } & \multicolumn{4}{|c|}{ Telepuliéskategóriák } \\
\hline & & $\mathrm{tl}$ & $\mathrm{t} 2$ & $\mathrm{t} 3$ & t4 \\
\hline \multirow{20}{*}{$\begin{array}{l}4270 \text { Rako- } \\
\text { mánykezelés }\end{array}$} & Budapest & & & & 519 \\
\hline & Baranya & 371 & 413 & 443 & \\
\hline & Bács-Kiskun & 361 & 402 & 431 & \\
\hline & Békés & 388 & 432 & & \\
\hline & Borsod-A.-Z. & 343 & 382 & 410 & \\
\hline & Csongrád & 410 & 457 & 490 & \\
\hline & Fejér & 435 & 484 & 519 & \\
\hline & Győr-M.-S. & 413 & 460 & 493 & \\
\hline & Hajdú-Bihar & 397 & 442 & 474 & \\
\hline & Heves & 378 & 421 & & \\
\hline & Komárom-E. & 365 & 406 & & \\
\hline & Nógrád & 383 & 426 & & \\
\hline & Pest & 396 & 441 & & \\
\hline & Somogy & 348 & 388 & & \\
\hline & Szabolcs-Sz.-B. & 305 & 340 & 364 & \\
\hline & Jász-N.-Sz. & 391 & 435 & & \\
\hline & Tolna & 373 & 416 & & \\
\hline & Vas & 434 & 483 & & \\
\hline & Veszprém & 348 & 387 & & \\
\hline & Zala & 345 & 384 & & \\
\hline
\end{tabular}

Forrás: A pénzügyminiszter 7002/1999. (PK. 13.) irányelve 1999.

A táblázat a következő kategóriákat alkalmazza: A szakmabesorolások az APEH szakmai kódrendszere alapján történtek, melyen belül egyes hasonló és rokon szakmákat csoportokba sorolva kezeltek. A szakmakategóriák száma így is kb. négyszázra tehetö.

A területi sajátosságok a táblázatban egyrészt a $19+1$ megye, másrészt a négy településnagysági csoport keretében kerülnek a rendszerbe. A PM által használt településkategóriák az 5000 lakos alatti (t1), az 5000-100000 lakos közötti (t2), a 100000 lakos feletti települések ( $\mathrm{t} 3$ ) csoportjai, valamint a fóváros ( $\mathrm{t} 4)$, mint kủlön egység.

Az APEH és a PM ezzel mintegy elismertté és legitimmé tette azt a tényt, hogy az egyéni vállalkozások területi sajátosságai ${ }^{4}$ befolyásolhatják az elérhetỏ jövedelmeket. Mindezt persze rendkívül leegyszerüsített formában, mindössze a megyék és a széles telepủléskategóriák tág határai között jelentik ki, részletesebb területi differenciákba nem mennek bele. A részletesebb elemek hiánya - mondhatni teljesen kézzel fogható - módszertani és elvi okokra vezethető vissza. Bármennyire kicsiny területegységet is veszünk alapul, nem várható el a helyi egyéni vállalkozótól, hogy közel ugyanannyi jövedelmet tudjon felmutatni, mint a szintén helyben dolgozó és 
hasonló szakmát folytató kollégája, hiszen tevékenységét ezen kívül sok más tényezö is befolyásolhatja. Itt ezért ismételten le kell szögezni, hogy a listán szereplő számadatok nem elvárt jövedelmi szintek, nem is minimális lehetséges jövedelmi értékek, hanem kizárólag kiválasztási szempontok.

A dokumentum kialakításának módszertanából fakađóan sem lehetett részletesebb területi bontást kialakítani. A táblázat megalkotásának első lépése az alapul szolgáló adatbázis kialakítása. Ehhez a minisztériumnak a vállalkozások által benyújtott adóbevallásokon kívül más adatbázis nem áll rendelkezésére. Az APEH SZTADI ${ }^{5}$-nál rendelkezésre álló adatokból az aktuális évet megelőző évi adatokat (50\%-os súllyal), az azt megelőző évit (30\%-os súllyal) és az azelöttit (20\%-os súllyal) alkalmazzák. Az adatbázist első lépésben országos szinten állítják össze, amelybe csak azon egyéni vállalkozók jövedelemadatai kerülnek be, akik tételes költségelszámolást alkalmaznak, nem tevékenységüket kezdők, teljes évben tevékenykedök, az év folyamán telephelyet nem változtattak és fóállású vállalkozók ${ }^{6}$. Az országos adatbázist ezután két szempontból is górcső alá veszik. Egyrészt létrehozzák a szakmánként képzett átlagos jövedelemértékeket (ezek tehát országos szakmai átlagok), másrészt megnézik, hogy az egész adatbázisból milyen megyei és településnagyság szerinti kép rajzolódik ki. Az egyes szakmákra kapott országos átlagjövedelmi értékeket szintrehozással, korrekciókkal ${ }^{7}$ az aktuális bevallási célévre elöreszámítják, s végül ezek ismeretében kialakítják a bevallás-kiegészítésre mértékadó összeghatárokat.

Az összeghatárok kialakítása a következő képlettel írható le (Szatmári 1997):

$\mathrm{KÖ}=\mathrm{KBJ} \times \mathrm{M} \times \mathrm{T}$

ahol: KÖ = a bevallás-kiegészítésre mértékadó összeghatár

$\mathrm{KBJ}=$ a korrigált bevallott jövedelem

$\mathrm{M}$ = a megyei szorzó

$\mathrm{T}=\mathrm{a}$ településnagyság szorzója

A megyei és településnagysági értékek tehát nem az egyes megyék és településkategóriák kizárólagosan saját elemeiböl képzett átlagok, hanem az országos átlagokból visszaszámolt adatok. Erre azért volt szükség, mert az egyes szakmákban, megyékben és településkategóriákban nem lenne elegenđö számú elem ahhoz, hogy megfelelöen megbízható átlagadatokat képezhessünk belölük. A részletesebb területi bontásnak szintén az az akadálya, hogy az egyes kisebb területegységekre (pl. kistérségekre vagy településekre) nézve túlontúl kis sokasággal lehetne csak dolgozni.

Az egyes szakmai alapadatokra a területi differenciálás szorzóit sablonszerüen húzták rá a készítők. Az irányelvben közölt táblázatban így végül szakmánként azonos területi szerkezetủ adatsorokkal találkozhatunk. Ez azt jelenti, hogy nem érvényesül az egyes szakmák helyi jellegböl adódó jövedelmezőségi differenciáltsága, minden egyes szakma esetében ugyanazokban a körzetekben (megyékben, településkategóriákban) lesz magasabb a bevallás-kiegészítésre mértékadó összeghatár, mint más szakmák esetében, ráadásul a szakmákon belül a különbözö területegységek közötti arányok teljesen hasonlóak lesznek a többi szakmáéhoz. 
A területi alapú gondolkodás a PM ezen dokumentumában még egy helyen, az eddigiektől eltérően ủj fogalmakkal jelenik meg. Másképpen kezeli ugyanis az irányelv a területfejlesztés kedvezményezett térségeiben tevékenykedỏ vállalkozókat. Az irányelv szerint el lehet tekinteni a bevallás kiegészítésére való felszólítástól, ha az adózó mezögazdasági vagy ipari szakmacsoportba sorolt tevékenységet végzett, és telephelye mezőgazdasági, vidékfejlesztési vagy ipari szerkezetátalakitási övezetben volt, illetve akkor is, ha telephelye társadalmi-gazdasági szempontból elmaradott és tartós munkanélküliséggel sújtott településen volt. A konkrét érintett területekröl - az irányelv szerint is - a 19/1998. (II. 4.) kormányrendelet nyilatkozik.

\section{2) A dokumentumból kirajzolódó térszerkezeti kép}

A pénzügyminisztériumi irányelvhez csatolt táblázat adatsora csak egy halvány számrendszer, a kiválasztási szempontok listája és nem konkrét térségi jövedelmi fogódzók halmaza. A dokumentumból kiszürhető térszerkezeti kép ezért inkább a kiválasztási összeghatárok területi struktúráját adja.

A dokumentumból a területi kutatókat leginkább az a területi sablon érdekelheti, melyet az egyes szakmai átlagadatokra ráhúzva a táblázat részletes számértékeit számíthatjuk ki. A térszerkezeti analízishez és az ábrázoláshoz az adatbázis megfelelő átalakítása szükséges. A rendkívül nagy méretủ táblázatsor adataiból egy összevont, leegyszerüsített és átlagosnak mondható helyzet kialakítása látszik célszerünek. Elkészithető egy, az összes szakmai táblából egyszerü átlagolással képzett tábla, majd ennek a táblázatnak az értékeit a tábla saját átlagának százalékában érdemes feltüntetni. A táblázat egyes cellái ezzel összehasonlíthatóvá válnak, így térképezésük is lehetséges lesz.

A térszerkezeti analízishez kapcsolódó térképeket településnagyság-csoportok szerint készítettük el. Az első térkép az átlagos minimáljövedelmek (illetve kiválasztási határértékek) eltéréseit mutatja az országos átlagtól az 5000-nél kevesebb lakosú településeken megyénként, a második az 5000-100 000 lakosú telepủlések, a harmadik pedig a 100000 fónél népesebb települések és a főváros esetében mutatja ugyanezt (1. ábra).

A térképeken jól látható, hogy általában a népesebb telepúléskategóriákban magasabb, míg a kisebb népességűekben alacsonyabb a bevallási küszöb. Egy-egy megyét kiválasztva és három adatát összehasonlítva minden esetben a népesebb településcsoportba tartozóknál fogalmaz meg magasabb minimális jövedelmi szintet az adóhatóság. Az viszont nem feltétlenül igaz, hogy ha egy vállalkozó egy népesebb településen tevékenykedik valamelyik megyében, akkor biztosan magasabb a jövedelmi küszöbértéke, mint ha alacsonyabb településkategóriában és egy másik megyében dolgozna. Szabolcs-Szatmár-Bereg megye legnagyobb településén sem olyan magas a bevallás-kiegészítésre mértékadó összeghatár, mint például Fejér megye legkisebb népességủ kategóriája esetében. 


\section{1. ÁBRA}

A bevallás-kiegészitésre mérvadó átlagos összeghatárok az egyes településkategóriákban megyénkẻnt

(Averages Amounts Concerning to the Supplement of Income Return in the Individual Categories of Settlements by Counties)

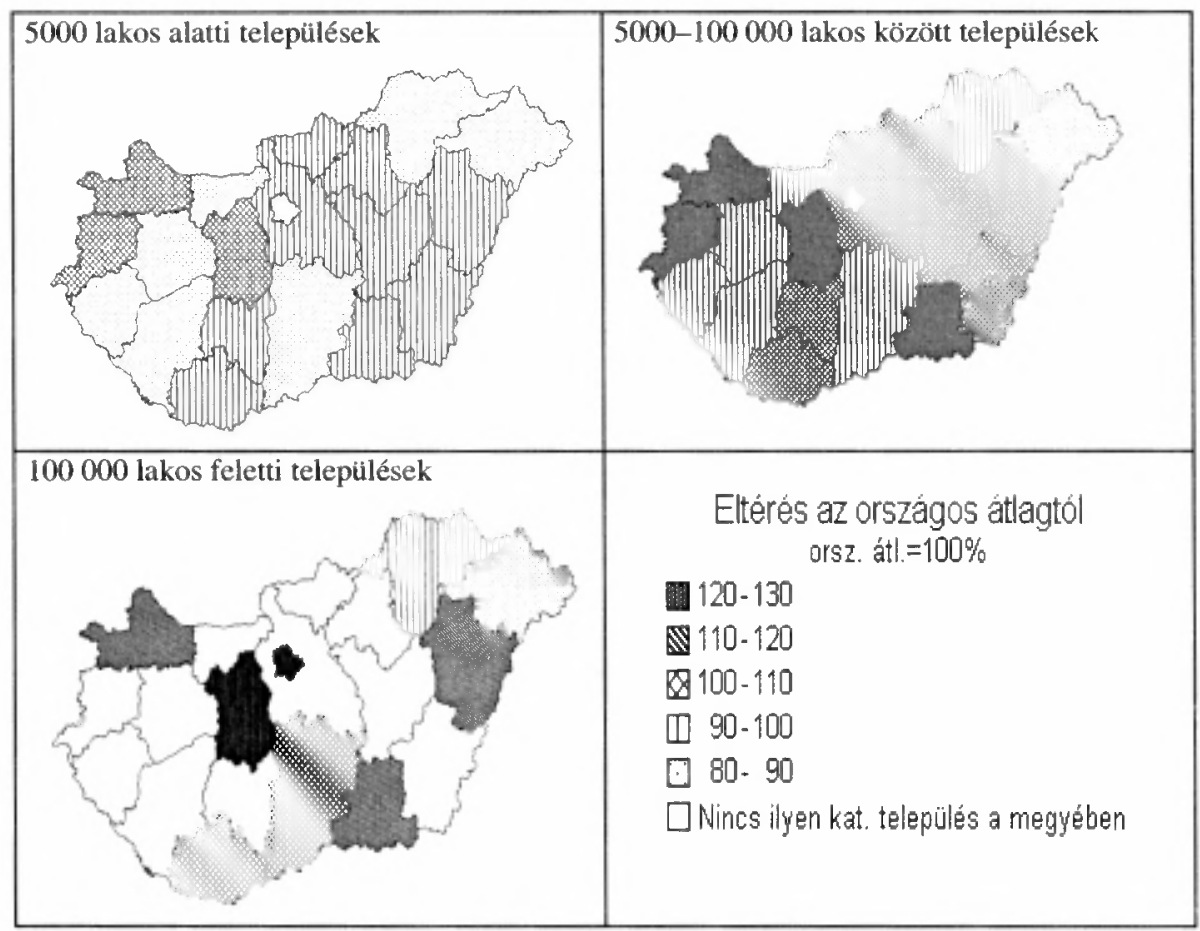

Forrás: Saját szerkesztés.

A településkategóriákon belüli szórás, illetőleg a térképeken a színkategóriák száma a magasabb településnagyság-csoportok felé növekszik. Míg az 5000 lakos alatti csoportban relatíve homogén térrel találkozunk, addig a 100000 fö felettiben kimondottan sokszínü a kép.

A megyék közötti viszonyokat nézve összességében - legalábbis az 1999-es évre készült irányelv szerint - Budapesten illetve Fejér megye 100000 fönél népesebb településén, azaz Székesfehérváron legmagasabb a kiválasztási összeghatár. Fejér mindegyik településkategória esetében a legnagyobb küszöbértékú, hasonlóan magasak a Györ-Moson-Sopron és Vas megyẻhez tartozó értékek.

Az országban megszokott területi jövedelmi differenciáknak, más szóval a Dunántúl Alföldnél jobb helyzetének (Kovács 1996) látszik ellentmondani, hogy mind a legkisebb, mind pedig a közepes településkategóriánál az Alföld legnagyobb részének megyéi (valamint néhány észak-magyarországi megye is) magasabb bevallási összeghatárokkal rendelkezik, mint a Dunántúl kétharmada. Ez a területi szerkezet föként a PM számítási módszeréböl adódik így. 


\section{3) A dokumentum használata a jövedelem terïleti különbségeinek vizsgálatához}

Akár jövedelembecsléshez, akár a jövedelem területi differenciáltságának kutatásához kívánjuk használni az irányelvben közölt területi adatbázist, csak alapos fenntartásokkal tehetjük azt. Az adatbázisból nyerhetỏ térszerkezeti kép ugyanis nem a jövedelemnagyság egy meghatározó befolyásoló tényezőjének vagy összetevőjének területi alakulását mutatja. Puritánul fogalmazva - ahogyan ezt a dokumentumot készítő PM Adóigazgatási főosztállyal készített interjúnk során is hallottuk - ,nem szabad tudományos szinten komolyan venni az irányelvből kiolvasható területi tendenciákat".

A jövedelem területi szerkezetét kutatók számára a legfóbb tanulság az lehet, hogy immáron a Pénzügyminisztérium is felismerte (illetve kezdi felismerni), hogy nem számíthat az egyéni vállalkozóktól azonos nagyságú minimáljövedelmekre az ország különböző megyéiben és eltérő nagyságú településein. A PM engedékenyebbnek tünik azokkal a területekkel szemben, amelyekben - a számításai alapján feltételezhetöen - nehezebb jövedelemszerzési körülmények között tevékenykednek a vállalkozók. Ez a felfogás és a hozzá tartozó területi kép pedig már inkább a területi kutatók számára nyújt alapot a továbbgondolásra.

\section{Jegyzetek}

${ }^{1}$ A becslés intézménye nem új keletü dolog. Az ötvenes évektől a magánvállalkozói jövedelemadóztatás legkeményebb, gyakran kétes törvényességí adóeszközei közé tartozott. Az akkori tanácsi adóhatóśgok szinte bármikor bevethették ezt az eszközt, s a kalkulált vagy összehasonlításon alapuló becslés eredménye tekintetében nem volt követelmény, hogy reális eredmények keletkezzenek. Az SZJA bevezetésekor e sok jogos kritikával illetett jogintézmény elünt és vele együtt a legkisebb adóköteles jövedelem módszere is. A becslés az 1990. évi XCI. törvénnyel ismét alkalmazható eszközzé vált.

2 Mivel az adóapparátus múködése még kevésbé volt hatékony, pontosabban a lebukás kockázata nem volt kellően elrettentő erejü, továbbá már lassanként versenypiaci hátrányt jelentett, ha valaki nem élt az adómanipuláció lehetôségével, a magyar adózók egyre szélesebb körében terjedt el az adókikerülés gondolata.

3 Az 1990. évi XCI. törvény 60. §-ának módosítását az 1995. évi CX. törvény rögzíti. Ettől kezdve létezik a pénztigyminiszteri irányelv intézménye (1990. évi XCI. törvény 60. §-ának (7) bekezdése).

4 A települési besorolást - több telephely esetén - az elso helyen feltüntetett telephely alapján célszerü figyelembe venni. Az év közben telephelyet változtató vállalkozóknál időarányos értékkel kell dolgozni.

5 APEH Számítástechnikai és Adóelszámolási Intézet

${ }^{6}$ Az adatbázisba nem veszik bele továbbá a 10 milliós értékhatár fölött vallókat sem.

${ }^{7}$ Figyelembe veszik például a következ̋ évi várható bruttó keresetnövekedés ütemét is.

\section{Irodalom}

A pénzỉ gyminiszter .../1997. (PK. ...) irányelve/tervezet/. - Adó. 14. 12-72. o.

A pénzligyminiszter .../1998. (PK. ...) irányelve. - Adó. 1-2. 32-109. o.

A pénzügyminiszter 7002/1999. (PK. 13.) irányelve. - Adó. 15-16. 7-43. o.

Földes G. (1998) Egy ritkán alkalmazott eszköz: az adóbecslés. - Adóvilág. 5. 19-28. o.

Hadi L. (1995) Az adózás rendjének 1996. évre tervezett módosításai. - Adó. 13. 8-12. o. PM Adóigazgatási fóosztály.

Kovács Cs. (1996) Térbeli jövedelmi viszonyok Magyarországon 1994-ben. Budapest, KSH Gazdaságelemzési és Informatikai Intézet.

Szatmári L. (1995) Változások az adóalap becslésének módszereiben. - Ado. 14. 926-928. o.

Szatmári L. (1997) A jövedelemalapú becslésrớl. - Adóvilág. 2. 2-10. o. 


\title{
SPACE IN THE TAX SYSTEM: THE APPEARANCE OF REGIONAL THINKING IN A DOCUMENT OF THE MINISTRY OF FINANCE
}

\begin{abstract}
ÁKOS JAKOBI
Since 1996 the Hungarian Ministry of Finance put down a directive for the tax office (APEH) regarding the self-employed private individuals to supplement their income tax returns. According to this document one has to be called upon, whose returned income does not meet the limit which is equivalent to the minimum wages, professional and regional characteristics.

The importance of this document is that the Ministry of Finance - as a governmental institution - begins to recognise the importance of regional inequalities in its own thinking. The ministry uses such notions as: settlement-size categories, counties, preferential areas of regional development and politics (etc.).
\end{abstract}

